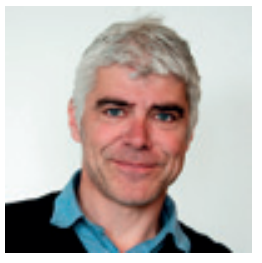

\title{
Er fattige i sør hjelpeløse klienter?
}

\begin{abstract}
Mediene og det internasjonale samfunnet etterlater et inntrykk av at folk som mottar utviklingsbistand eller nødhjelp er passive ofre ute av stand til å gjøre noe med sin egen situasjon. Fokus på «hjelp utenfra» og «humanitær krise» gjør mennesker til klienter. Det er det motsatte av det de trenger i en politisk kamp mot urettferdighet, krig og fattigdom.
\end{abstract}

Dette slo meg sterkere enn noensinne under krigen i Gaza ved årsskiftet. Medier, politikere og organisasjoner hadde fokus på å «få inn hjelp utenfra». Spørsmålet som ble gjentatt i det utrettelige var «hva kan det internasjonale samfunn gjøre med den humanitære situasjonen?». Aldri fikk vi spørsmål fra journalister om hvilke ressurser befolkningen på Gaza selv har til å møte en humanitær krise. Dette norske mediebildet har bidratt til klientifisering av palestinerne som befolkningsgruppe.

I de tre ukene krigen varte, og i ukene etterpå, satt jeg i en rekke intervjuer om situasjonen på Gaza basert på informasjon som vi etter beste evne hadde hentet fra våre egne ansatte på Gaza-stripen. I etterkant slår det meg at ingen norsk journalist var opptatt av befolkningens egne ressurser. De var utelukkende opptatt av hva norske organisasjoner og det internasjonale samfunn kunne gjøre for å redde befolkningen ut av krisen og få inn forsyninger utenfra. Medieretorikken var knyttet til «ute» og «inne», hvor de utenfra måtte hjelpe de som var «inne».

Norsk Folkehjelp representerte faktisk begge sider. Vi er en norsk organisasjon (ute), men våre ansatte på Gaza er lokale palestinere (inne), og prosjektene vi støtter drives av palestinske partnerorganisasjoner, slik vi fak- tisk jobber i alle våre utenlandsprogrammer. Da jeg fikk spørsmål om hva «vi» kunne gjøre, var fokuset fra journalistene hva vi norske kunne gjøre. Jeg kan ikke huske et eneste spørsmål der mediene prøvde å utforske palestinernes egne ressurser. Mønsteret som ble skapt var at befolkningen på Gaza var passive klienter, og at de manglet ressurser, initiativ og evne til å gjøre noe med egen situasjon. Parallelt hadde det internasjonale samfunn, representert ved vestlige velgjørende organisasjoner, ressurser, kraft og initiativ. Det er en interessant parallell til det norske helsevesen. Oppegående krefter $i$ helsevesenet er opptatt av at pasientene ikke skal gjøres til hjelpeløse klienter. Da blir de fratatt ressursene til å hjelpe seg selv - noe som kan føre til at de blir dårligere.

Det er selvsagt ikke slik at alle journalister hadde en klientifiserende tilnærming til krigen i Gaza. Flere reportere, spesielt de med fartstid fra området, var tidvis mer nyansert. Og klientifiseringen var neppe bevisst. Vi står nok heller overfor en vanetenking i beskrivelsen av humanitære kriser og omfattende fattigdom. Sjelden etterspørres lokalbefolkningens egne ressurser. For mediene er det bedre stoff å få frem heltemodig livreddende innsats fra «hvite riddere» utenfra.

For oss i Norsk Folkehjelp som kommer fra Norge, men som også representerer lokalt ansatte og lokale partnere, er denne klientifiseringen krenkende. Vi vet gjennom mange års arbeid med grasrotorganisasjoner på Gazastripen, i Afrika og LatinAmerika at problemene ikke handler om mangel på evner, initiativ og ressurser i lokalbefolkningen, men om krig, okkupasjon og urettferdig fordeling av makt og ressurser. Det som er slående og som burde fått mer oppmerksomhet, er for eksempel hvordan det palestinske samfunnet ved oppfinnsomhet og ukuelig vilje finner kriseløsninger som får samfunnsfunksjoner og familieliv til å gå rundt på et vis, på tross av konflikten og blokaden.

Mønsteret som medier og det internasjonale samfunn skaper understøtter dessverre Israels politikk gjennom mange år for å «avvikle» Gaza som et normalt og levedyktig samfunn. Systematisk hindring av palestinsk næringsutvikling har kulminert med systematisk bombing av infrastruktur. Over $90 \%$ av næringsvirksomheten ligger brakk, mens $80 \%$ av befolkningen er blitt gjort avhengig av humanitær hjelp. Dette er ingen naturkatastrofe, men en villet politikk. Slik oppnår Israel at det internasjonale samfunnet og medier blir opptatt av Gazastripen som et humanitært problem snarere enn som en verdig befolkning med sivile, politiske og sosiale rettigheter som systematisk brytes av okkupasjonsmakten. Den politiske kampen og palestinernes egne ressurser forsvinner ut av bildet.

Spørsmålet vi må stille oss, er om ikke dette reflekterer et generelt problem. Urettferdighet kan ikke bekjempes med klientifisering. Klientifisering av folk som sliter seg gjennom flom, hungersnød og krig, er nedlatende, uetisk og umoralsk. Den representerer et gufs av holdninger som de færreste vil vedkjenne seg. Politisk vanetenking og overfladisk retorikk og journalistikk skaper mønstre av holdninger som får politiske konsekvenser. Ved å fremstille folk som passive objekter, gjør vi dem og deres sak en bjørnetjeneste. Lokalbefolkningen sitter på den beste informasjonen og ofte de beste løsningene. I et slikt perspektiv er politisk støtte viktigere enn størrelsen på giverlands pengebinge.

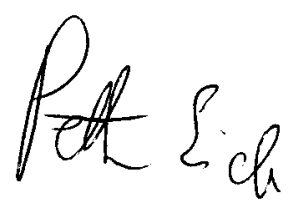

\section{I neste nummer:}

Muskelrelakserende midler

Brystkreft

Kjønn og legemidler
Kjønnskorrigerende kirurgi

Chlamydia

Regionalanestesi 